\title{
EDITORIAL
}

\section{The ICTY and the Right to a Fair Trial: A Critique of the Critics}

Keywords: fair trial; International Criminal Tribunal for the former Yugoslavia.

In recent publications a rising tide of criticism directed against the International Criminal Tribunal for the former Yugoslavia (ICTY) is discernible, principally concerning whether or not the ICTY grants the accused a fair trial. The perceived lack of ability, or willingness, to satisfy the highest standards of human rights concerning the right of accused to a fair trial is regarded as a death-knell both for the broad acceptance of the ICTY's jurisprudence as well as the prospects for a permanent international criminal court. While most of the criticism centres around the interpretation and application of provisions of the ICTY's Statute and Rules of Procedure and Evidence addressing the right to a fair trial, some of it concerns the vigorousness with which ICTY officials insist upon the surrender of indicted persons. With all due respect these commentators, by applying norms that are not wholly applicable, misconceive the threat to the accused's fair trial rights.

The first, general area of criticism concerns the activeness with which certain officials have sought to ensure that the ICTY is able to perform its principal function of trying individuals accused of serious violations of international humanitarian law in the former Yugoslavia. Because of a belief that the presence of the accused is essential to ensure a fair trial, the Judges decided that, unlike many national legal systems, the ICTY would not conduct trials in absentia. The presence of the accused is therefore necessary for the ICTY to perform its function. In response to actions taken to ensure such presence one commentator noted with dismay that ICTY President Antonio Cassese has been "very outspoken" about the need to bring the accused to trial, and as evidence referred to his June 1996 recommendation that Bosnian elections be postponed until the indicted 
Bosnian Serb leaders Radovan Karadžić and General Ratko Mladić were arrested, and that 'Serbia' be excluded from the 1996 Olympic games until it helped to arrest the two men. He then questioned the appropriateness of this "prosecutorial zeal" from the President of the tribunal before which these two men would be tried. ${ }^{1}$ Another writer argued that the President "stretched" his judicial role, asserting that, "[i]t is surely not the business of Judges to call for political action, including economic sanctions, against any group. Crusading and judging are different (and incompatible) occupations".?

This 'prosecutorial zeal' is, in fact, only an expression of concern about the efficacy of the ICTY, as well as international law in general, which requires states to comply with their obligations under Article 29 of the Statute to cooperate with the ICTY by means of, inter alia, the execution of arrest warrants. The President, unlike the Prosecutor, does not choose who is indicted, but insists only that those who are indicted should be surrendered if possible. The public stature of these two figures, $\mathrm{Mr}$. Karadžić and General Mladić, renders the flouting of this obligation all the more untenable. Implicit is the recognition that it might be worse for the rule of law to have an international criminal tribunal that is ignored than not to have one at all. As a former Chief Justice of the US Supreme Court commented in relation to the early years of that court, "[t]he Court could stand hard blows, but not ridicule". ${ }^{3}$ As former Prosecutor Justice Goldstone asserted, "[a] criminal justice system lacking in credibility and enforcement cannot provide justice to victims or deter future criminals". ${ }^{4}$ Justice Goldstone went on to note that if there were no additional meaningful arrests the ICTY would be prevented from carrying out its mandate, and "war crimes victims will be dealt another blow", as will the credibility of the Security Council, "whose binding resolutions about enforcing tribunal orders are being disobeyed". Such an occurrence would, amongst other effects, bode ill for the establishment of a permanent international 
criminal court which, in the opinion of many, is the best method for preventing future crimes.

This argument, that the strenuousness with which ICTY officials call for the surrender of indictees prevents the accused from receiving a fair trial, is ill-informed. In the context in which the ICTY operates, without a police or security force and where it is dependent on national authorities to such an extent that it is, as described by President Cassese, "like a giant who has no arms and legs", ${ }^{6}$ these comments are a natural and logical occurrence. The ICTY must rely on the cooperation of states, being unable to take action itself, and one way to encourage cooperation is to call attention to its absence, thus generating support in the world community. If states, or for that matter national entities or multinational forces, were willing to cooperate fully by surrendering indictees and thereby allowing the ICTY to carry out its function, without the need for reminders, then such actions would prove unnecessary. Given, however, the situation as it stands, these activities are a necessary component of the President's function and do not diminish his judicial role or the ability of the ICTY to guarantee the accused a fair trial.

In addition to these general comments about the ICTY's ability to guarantee the accused a fair trial, the other principal area in which the ICTY has been criticized is in its application of the concept through its interpretation of its Statute and Rules. It was the August 1995 Decision by Trial Chamber II in the Tadic case concerning the Prosecutor's request for protective measures for victims and witnesses, and the Trial Chamber's interpretation and application of the dual obligations of a fair trial for the accused (Article 21), subject to protection for victims and witnesses (Article 22), that has been the subject of criticism. ${ }^{7}$

In response to the Prosecution's request the Trial Chamber granted certain Prosecution witnesses protective measures aimed at ensuring confidentiality (non-disclosure to the public and the media), and some witnesses were additionally granted anonymity, whereby their identities were not disclosed to the accused or counsel. Although the granting of anonymity was made dependent on the fulfilment of strict criteria, ${ }^{8}$ the decision to

6. The President's Second Report to the United Nations General Assembly, 7 Nov. 1995, reproduced in 1995 Yearbook of the ICTY 311 (1996).

7. Prosecutor v. Tadić, Decision on the Prosecutor's Motion for Protective Measures for Victims and Witnesses, Case No. IT-94-1-T, T. Ch. II, 10 Aug. 1995 (Victims and Witnesses Decision).

8. Id., at paras. 62-66. For a description of the ICTY's activities with regard to witness protec- 
grant anonymity has been the main source of contention for critics. One such critic wrote that the use of unidentified witnesses would deny the accused the right to a fair trial and to examine witnesses against him, as required by the Statute and international law, and in this regard notes that neither the International Covenant on Civil and Political Rights (ICCPR) or the European Convention on Human Rights (ECHR), both of which provide for the right to a fair and public hearing, subject these rights to the protection of victims and witnesses. ${ }^{9}$

These comments seem to be based upon a superficial reading of the Trial Chamber's Decision. Everyone, including the Trial Chamber, agrees that it is imperative that the accused should receive a fair trial. The fundamental issue remains what is necessary to achieve fairness. In answering this question the Trial Chamber considered the role of other international judicial instruments in applying and interpreting its obligations under the Statute and Rules. The Trial Chamber, while noting that Article 21 of the Statute reflects the standard of due process set forth in Article 14 of the ICCPR, stated that "the terms of that provision must be interpreted within the context of the 'object and purpose' and unique characteristics of the Statute" ${ }^{10}$ and among these unique characteristics is the affirmative obligation to protect victims and witnesses. In this regard the Trial Chamber considered it relevant that the ICTY was operating in the midst of an, at that point, on-going conflict and is without a police force or witness protection programme to provide protection for victims and witnesses. According to the Trial Chamber these considerations are unique, as neither Article 14 of the ICCPR nor Article 6 of the ECHR list the protection of victims and witnesses as one of its primary considerations and, "[a]s such, the interpretations given by other judicial bodies to Article 14 of the ICCPR and Article 6 of the ECHR is only of limited relevance"11 in applying provisions of its Statute and Rules. Added support for this position was found in the different circumstances in which the provisions apply, as is evidenced by the fact that the ICTY adjudicates crimes which are considered so horrific as to warrant universal jurisdiction. Similarly, it adjudi-

tion see Y.M.O. Featherstone, The International Criminal Tribunal for the Former Yugoslavia: Recent Development in Witness Protection, 10 LJIL 179 (1997).

9. M. Leigh, The Use of Unnamed Witnesses Against Accused, 90 AJIL 235 (1996).

10. Victims and Witnesses Decision, supra note 7, at para. 26.

11. Id., at para. 27. See also Prosecutor $v$. Landžo, Delić, Delalić and Mucić, Decision on Delalić's Motion for Provisional Release, Case No. IT-96-21, T. Ch. II, 25 Sept. 1996. 
cates crimes that were committed during war, thus presumably it would be entitled like military courts or other courts during "time of public emergency", ${ }^{12}$ to utilize more limited rights of due process, although the conclusion of a hostile peace limits the continued persuasiveness of this argument. The ICTY has not, however, chosen for more limited rights of due process. It ensures the accused a fair trial, but in determining what is fair it must also consider other interests deserving of protection, including the mandated interest to protect victims and witnesses. Thus the Statute and Rules provide the framework in which the meaning of 'fair trial' is determined and the ICTY is not bound by interpretations of other judicial instruments that are suited for a different context.

Included in this determination is the danger facing witnesses who testify before the ICTY. Failure to grant adequate protection places witnesses, so to speak, between Scylla and Charybdis: either they testify and relinquish at least temporarily the possibility of returning to their homes or the homes of friends and relatives located in territory controlled by, or easily accessible to, forces of the party against which they testify, or they do not testify and watch their hopes of justice fade away. The rights of the accused cannot be allowed to take unlimited precedence over all else and the interest in the safety of victims and witnesses is also part of the "broader interest of the international community in the pursuit of justice". ${ }^{13}$ That is not to say that the accused's fair trial should be jeopardised. It is still necessary to be found responsible for the crime and that finding must occur within the context of a trial that is 'fair' and provides for the rights of the accused, but not to the exclusion of all others. Law is, as the phrase 'ius est ars boni et aequi' ${ }^{14}$ indicates, a question of finding a balance between different interests, and in this case the balance is between measures deemed important, although not necessarily essential, to ensuring accused a fair trial and protection of victims and witnesses.

In this regard it is evident that despite some added difficulties, accused before the ICTY are guaranteed a fair trial, even considering the possibility of the use of anonymous witnesses. Several points should be considered.

12. Art. 4 of the ICCPR allows for the derogation of certain obligations under the Convention, including those contained in Art. 14, during "time of public emergency which threatens the life of the nation and the existence of which is officially proclaimed" to the "extent strictly required by the exigencies of the situation"; ICCPR, 6 ILM 368 (1967).

13. C. Chinkin, Due Process and Witness Anonymity, 91 AJIL 75, at 76 (1997).

14. P. Inventius Celsius, +140 . 
Firstly, the Trial Chamber did not simply grant anonymity to all who asked, but instead established the existence of significant criteria that must be fulfilled before anonymity will be granted. This is clear not only in the Trial Chamber's Decision but also in other decisions, such as that of Trial Chamber I rejecting the Prosecution's request in the Blaskić case for a 'blanket' order preventing disclosure of the names of more than 70 witnesses to the Defence, ${ }^{15}$ although indicating in a subsequent decision that it would consider granting anonymity if the Prosecution submitted proof that the conditions laid down by Trial Chamber II were satisfied. ${ }^{16}$ Secondly, protective measures, including anonymity, are only granted to the extent that they are demonstrably necessary, and if at any time they are no longer required "they shall cease to apply or, if a less restrictive measure can secure the required protection, that measure shall be applied". ${ }^{17}$ Thirdly, if granted the measures in practice are not as onerous as they may appear. For example, anonymity was granted to four persons in the Victims and Witnesses Decision. Of these four two were not called to give evidence and one agreed to give evidence in public without any protection. Thus only one witness testified anonymously and in that case the practical arrangements in the courtroom were such that the defence counsel could view the witness and, although the accused could not see the witness, he could hear the undistorted testimony in the original language. ${ }^{18}$ Fourthly, protective measures have also been granted in regard to Defence witnesses to encourage them to come forward, including confidentiality, the granting of safe conduct whereby the witness is immune from prosecution while in The Hague to testify, and the use of video-conferencing whereby witnesses are permitted to give evidence from the former Yugoslavia using a satellite link and are thus not present in the courtroom. ${ }^{19}$ Fifthly, the Judges know

15. Prosecutor $v$. Blaskić, Decision of Trial Chamber I on the Protection of Witnesses and Start of the Trial, Case No. IT-95-14-T, T. Ch. I, 2 Oct. 1996.

16. Prosecutor v. Blaskić, Decision on the Application of the Prosecutor dated 17 October 1996 Requesting Protective Measures for Victims and Witnesses, para. 42, Case No. IT-9514-T, T. Ch. I, 5 Nov. 1996; see also Prosecutor v. Landžo, Delić, Delalić and Mucić, Decision on the Motions by the Prosecution for Protective Measures for the Prosecution Witnesses Pseudonymed "B" Through to " $\mathrm{M}$ ", paras. 60-63, Case No. IT-96-21-T, T. Ch. II, 28 April 1997.

17. Prosecutor $v$. Tadić, Decision on Prosecutor's Motion Requesting Protective Measures for Witness R, at 5, Case No. IT-94-1-T, T. Ch. II, 31 July 1996.

18. Featherstone, supra note 8, at 186.

19. Prosecutor v. Tadić, Decision on the Defence Motions to Summon and Protect Defence Witnesses, and On the Giving of Evidence by Video-link, Case No. IT-94-T-1, T. Ch. II, 
that the witness has testified anonymously, thereby limiting cross-examination, and that is taken into consideration when determining the value of that witness' evidence. In this regard the Judges provided guidelines to be followed in order to ensure a fair trial when evidence is taken from an anonymous witness. ${ }^{20}$ Finally, a good guard against the dangers that arise as a result of the protective measures is the adversarial process itself. $\mathrm{A}$ prime example is the case of witness $\mathrm{L}$ who, in the course of the Tadic case, lied under oath. His fabrication was discovered by diligent Defence investigation with, once the issue was raised, the assistance of the Prosecution.

Thus the ICTY, because of its complete reliance on the cooperation of states and national entities for, amongst other things, access to evidence, execution of arrest warrants and protection of victims and witnesses and their families, and its lack of equivalent means for accomplishing these tasks itself, is not in the same situation as national courts, the context of which international norms and instruments such as the ICCPR and ECHR were framed to address. If it had the full cooperation of states and other entities then it would be closer to a national situation where other international instruments, as well as judicial interpretations of the meaning of 'fair trial' in these instruments, would apply. A good indicator that the ICTY has not encroached too far on the traditional conceptions of the necessities for fair trials in domestic settings are the calls that the ICTY is not doing enough to protect victims and witnesses or has only barely achieved the correct balance. ${ }^{21}$

Olivia Q. Swaak-Goldman

25 June 1996. See Featherstone, supra note 8 at 191-194.

20. Victims and Witnesses Decision, supra note 7, at paras. 70-71.

21. See M. Rees \& S. Maguire, Rape as a Crime Against Humanity, Tribunal, Nov./Dec. 1996, at 8; see also Chinkin, supra note 13. 